Philip A. Meyers

\title{
Insights into deposition of Lower Cretaceous black shales from meager accumulation of organic matter in Albian sediments from ODP site 763, Exmouth Plateau, Northwest Australia
}

Received: 7 August 1995

\begin{abstract}
The amount and type of organic matter present in an exceptionally complete upper Aptian to lower Cenomanian sequence of sediments from ODP site 763 on the Exmouth Plateau has been determined. Organic carbon concentrations average $0.2 \%$. Organic matter is marine in origin, and its production and preservation was low over the ca. 20-million-year interval recorded by this sequence. Because this section was tectonically isolated from mainland Australia in the early Aptian, it better represents global oceanic conditions than the many basin-edge locations in which Albian-age black shales have been found. Formation of the basin-edge black shales evidently resulted from rapid, turbiditic burial of organic matter rather than from enhanced oceanic production or from basin-wide anoxia during the Albian.
\end{abstract}

\section{Introduction}

Black shales enriched in organic carbon accumulated at many locations around the world during the Early Cretaceous and particularly during the Aptian-Albian (Arthur et al. 1984; Hallam 1987; Stein et al. 1989), including several sites in the Indian Ocean (Meyers and Dickens 1992). The occurrence of Aptian-Albian sediments lacking elevated organic carbon concentrations is therefore noteworthy in the sections recovered by Ocean Drilling Program (ODP) legs 122 and 123 at sites offshore of northwest Australia (Haq et al. 1990, Gradstein et al., 1990).

Organic matter accumulation in marine sediments is influenced by a variety of processes. Concentrations of organic matter reflect the rates of delivery of material from marine and continental sources, the amount of dilution by

Philip A. Meyers

Marine Geology and Geochemistry Program, Department of Geological Sciences, The University of Michigan, Ann Arbor, Michigan 48109-1063, USA other sedimentary components, and the degree of postdepositional degradation. The nature of sedimentary organic matter is determined by its biotic sources, its transport routes, and also its degree of preservation. Information about many paleoceanographic parameters can therefore often be inferred from the organic matter contents of ancient sediments.

A nearly complete Albian nannofossil biostratigraphic sequence was recovered at ODP site 763 northwest of Australia (Bralower 1992), indicating that sediments at this location provide an exceptional record of late Early Cretaceous paleoceanographic conditions on the southern Neo-Tethyan margin. Implications of elemental and isotopic characterizations of the meager organic matter accumulations in these sediments are discussed in this report.

\section{Samples and analysis}

Oceanographic setting

The Exmouth Plateau on the northwestern Australian continental margin consists of rifted and deeply subsided continental crust isolated from the Australian shelf by the Kangaroo Syncline (Exon et al. 1982). Since the plateau became isolated from Australia in the Early Cretaceous, only limited delivery of terrigenous sediment has occurred, and the marly chalks that were subsequently deposited contain very little organic matter (Snowdon and Meyers 1992). The location of the Exmouth Plateau during the Albian (Fig. 1) was in temperate latitudes $40^{\circ}-50^{\circ}$ south of the equator on the southern margin of Neo-Tethys (Haq et al. 1990).

Sampling

A 184-m-thick upper Aptian-Albian-Cenomanian section was recovered at ODP hole $763 \mathrm{~B}$ on the Exmouth 
Fig. 1 Location of ODP site 763 and nearby DSDP site 263 on the southern margin of NeoTethys during the Albian. Paleoreconstruction is after Barron et al. (1981)

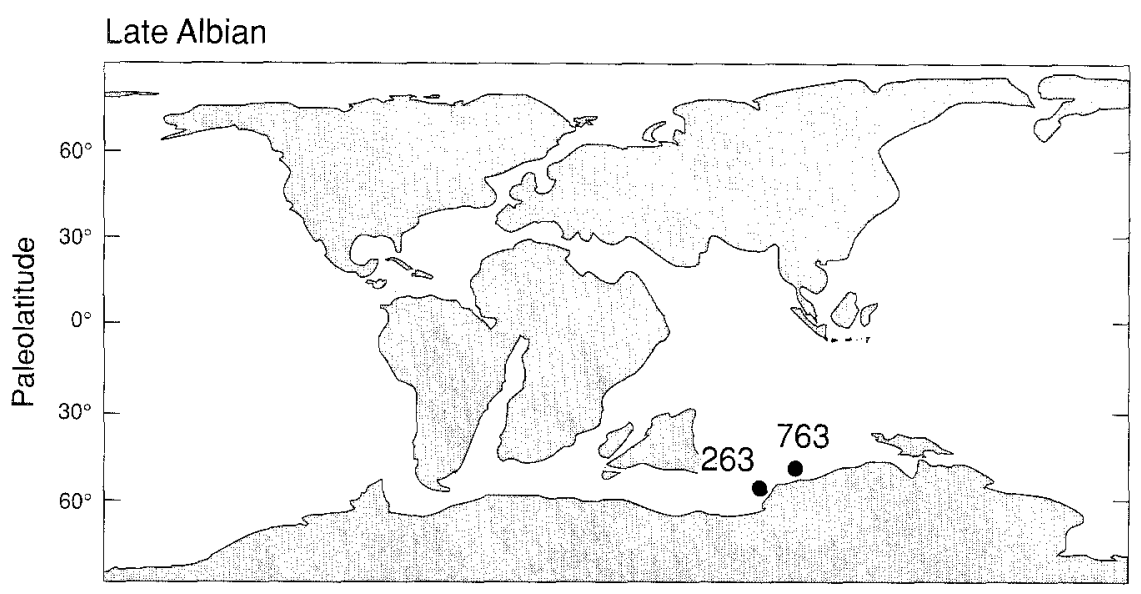

Plateau. The sediment consists of well-bioturbated, greenish gray, zeolitic nannofossil marlstone that was deposited at upper bathyal depths (Haq et al. 1990). Subtle lightdark changes in color occur at intervals corresponding to 20-40 ka per cycle and reflect variations between greater and lesser $\mathrm{CaCO}_{3}$ content. The section has a sedimentation rate that averages $10 \mathrm{~m} \mathrm{Ma}^{-1}$, and it contains an exceptionally complete Albian nannofossil biostratigraphy (Bralower 1992; Bralower and Siesser 1992). Sediment samples were obtained at intervals of $3 \mathrm{~m}$ through the Cenomanian and Albian portions of the section and at slightly larger intervals in the Aptian portion. A total of 34 samples was selected between 411 and $563 \mathrm{~m}$ below the sea floor (mbsf) in hole 763B.

\section{Analysis}

\section{$\mathrm{CaCO}_{3}$ concentrations}

Freeze-dried samples were analyzed for calcium carbonate using the carbonate bomb technique of Müller and Gastner (1971). Samples were reacted with $3 \mathrm{~N} \mathrm{HCl}$, and the volume of $\mathrm{CO}_{2}$ released was measured and compared to the volumes released from known amounts of pure $\mathrm{CaCO}_{3}$ to determine the percentage in each sample. The carbonate-free residue remaining after acid treatment was collected, rinsed, and dried for use in elemental $\mathrm{CHN}$ analyses and $\delta^{13} \mathrm{C}_{\text {organic }}$ determinations. Although a significant proportion of organic carbon and nitrogen can be lost from modern sediments in this procedure, the loss from geologically old sediments is not significant (Yamamura and Kayanne 1995).

\section{Carbonate $\delta^{18} O$ and $\delta^{13} C$ values}

Stable oxygen and carbon isotope ratios of bulk carbonates were determined from analyses done in the Stable Isotope Laboratory at The University of Michigan. Iso- tope measurement of bulk carbonate instead of picked microfossils has been demonstrated to be useful in investigations of carbon accumulation in marine sequences (Shackleton and Hall 1984; Weissert and Bréhéret 1991; Shackleton et al. 1993). Carbon dioxide was released by treatment of samples with phosphoric acid. The ${ }^{18} \mathrm{O} /{ }^{16} \mathrm{O}$ and ${ }^{13} \mathrm{C} /{ }^{12} \mathrm{C}$ ratios of the gas were measured using a Finnigan MAT model 251 mass spectrometer equipped with an automated analysis system. NBS standards are routinely and frequently used to calibrate the instruments. $\delta^{18} \mathrm{O}$ and $\delta^{13} \mathrm{C}$ values are reported relative to the PDB standard.

\section{Organic carbon and nitrogen concentrations}

Amounts of organic carbon and residual nitrogen were measured with a Carlo Erba 1108 CHNS-O analyzer. This procedure involves heating the sample at $1020^{\circ} \mathrm{C}$ and measuring the combustion products by gas chromatography (Verardo et al. 1990). Known amounts of sulfanilamide $\left(\mathrm{C}_{6} \mathrm{H}_{8} \mathrm{~N}_{2} \mathrm{O}_{2} \mathrm{~S}\right)$ are used to calibrate the instrument and to calculate the quantities of $\mathrm{C}$ and $\mathrm{N}$ released from the samples. Total organic carbon concentrations were then calculated on a whole-sediment basis, adjusting for the carbonate concentrations determined from the bomb technique. $\mathrm{C} / \mathrm{N}$ ratios were calculated on an atomic basis.

\section{Organic carbon $\delta^{13} C$ values}

Organic $\delta^{13} \mathrm{C}$ values were determined from analyses done in the Stable Isotope Laboratory at The University of Michigan. The ${ }^{13} \mathrm{C} /{ }^{12} \mathrm{C}$ ratios of the residual carbon were determined with a Finnigan Delta $\mathrm{S}$ mass spectrometer calibrated with the NBS-21 (graphite) standard. Combustion of the carbonate-free organic matter was done at $800^{\circ} \mathrm{C}$ in sealed Vycor tubes in the presence of $\mathrm{CuO}$ and $\mathrm{Cu}$. Data are corrected for ${ }^{17} \mathrm{O}$ and are expressed in conventional $\delta^{13} \mathrm{C}$ notation relative to the PDB standard. 


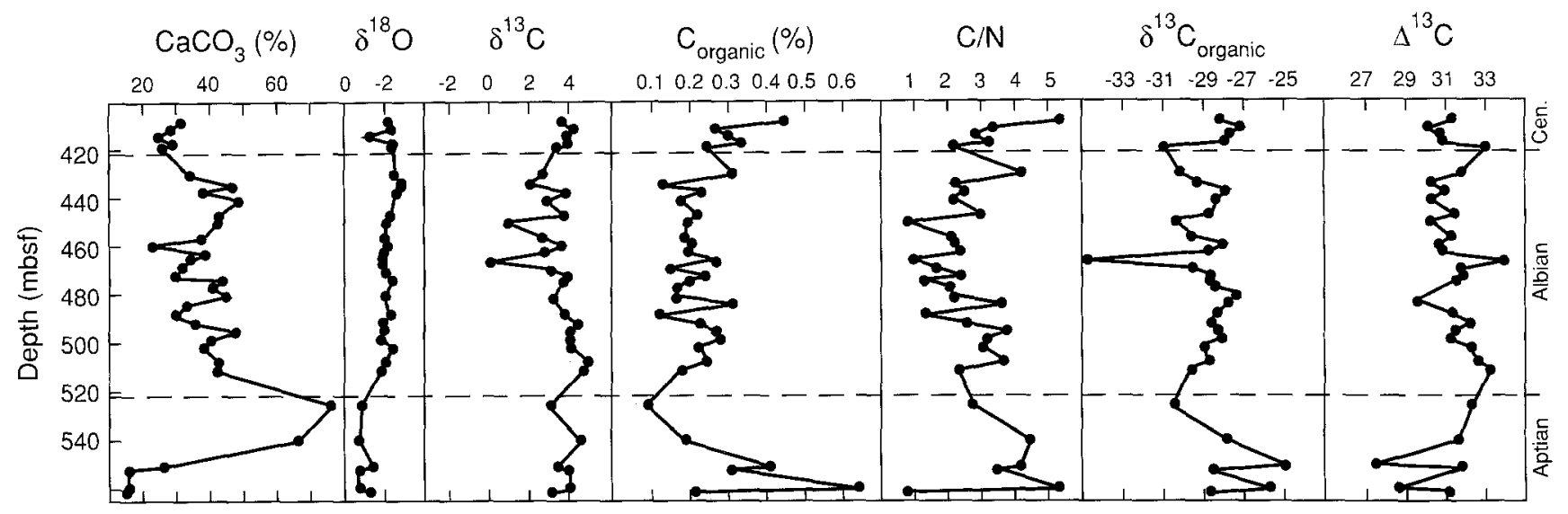

Fig. $2 \mathrm{CaCO}_{3}$ and organic carbon concentrations and isotopic compositions, organic matter atomic $\mathrm{C} / \mathrm{N}$ ratios, and the difference between carbonate and organic $\delta^{13} \mathrm{C}$ values $\left(\Delta^{13} \mathrm{C}\right)$ in sediments from hole 763B on the Exmouth Plateau, northwestern Australia. Age divisions are based on the nannofossil biostratigraphic divisions of Bralower (1992)

\section{Results and interpretation}

The results of measurements of $\mathrm{CaCO}_{3}$ and total organic carbon concentrations, organic matter $\mathrm{C} / \mathrm{N}$ and carbon isotope ratios, and sedimentation rates provide information about biological productivity and subsequent organic matter accumulation on the southern Neo-Tethys margin during the Albian.

\section{$\mathrm{CaCO}_{3}$ concentrations}

Calcium carbonate concentration patterns differ in the Aptian, Albian, and Cenomanian intervals of hole 763B (Fig. 2). Concentrations change radically from below $20 \%$ in mid-Aptian sediments to over $60 \%$ in sediments deposited in the latest Aptian. In contrast, concentrations fluctuate over a relatively narrow range $(20-50 \%)$ in Albian sediments. The early Cenomanian sediments have concentrations that cluster around $30 \%$.

Cyclical fluctuations in calcium carbonate concentrations are common features of pelagic and hemipelagic marine sediments deposited during the Early to middle Cretaceous in other parts of the world. Such cycles are well-developed in Cenomanian chalks of southern England (Ditchfield and Marshall 1989) and in Aptian-Albian marls in southeastern France (Weissert and Bréhéret 1991), for example. These fluctuations, often called "chalk-marl" cycles, result from the varying interactions of three main processes: carbonate dilution, carbonate dissolution, and carbonate production (e.g., Dean et al. 1981).

Variations in delivery of fine-grained clastic sediments from the Australian land mass would result in variable dilution of the calcium carbonate fraction of sediments. Coarser particles evidently settled prior to reaching the
Exmouth Plateau as a consequence of the isolation of this plateau from the mainland prior to the Aptian. The principal mode of transport from the landmass was probably fluvial, inasmuch as the paleolocation of site 763 was in temperate latitudes, which typically have relatively moist climates.

Carbonate dissolution in depths above the lysocline appears to be caused principally by microbial degradation of marine organic matter and the consequent production of interstitial dissolved carbon dioxide (Berger 1970; Berger et al. 1982; Emerson and Bender 1982). This dissolution is controlled by the availability of readily metabolized marine organic matter in sediments. Dissolution does not, however, appear to have been important in creating the carbonate concentration variations evident at site 763 , because the nannofossils are very well preserved (Bralower 1992; Bralower and Siesser 1992).

The lack of high-resolution time control in the site 763 section precludes reliable calculation of sediment mass accumulation rates, which would help determine the cause of the concentration variations, so inferences from the isotope record will be used instead. Changes in productivity should be recorded in the carbon isotopic contents of carbonates (Hayes et al. 1989) and organic matter (Dean et al. 1986).

Carbonate $\delta^{18} \mathrm{O}$ and $\delta^{13} \mathrm{C}$ values

The $\delta^{18} \mathrm{O}$ values of the late Aptian sediments are between $-0.6 \%$ and $-1.3 \%$, and those of the Albian and early Cenomanin sediments range from $-1.8 \%$ to $-2.8 \%$ (Fig. 2). The lack of major excursions from the estimated $\delta^{18} \mathrm{O}$ value of $-1 \%$ relative to SMOW for nonglacial Cretaceous seawater (Ditchfield and Marshall 1989) suggests that paleoceanographic conditions on the southern Neo-Tethyan margin were generally stable during the Late Cretaceous. An environmental change at the Aptian/ Albian boundary is indicated by the shift of ca. $-1 \%$, which corresponds to a temperature change of about $+4^{\circ} \mathrm{C}$ (Friedman and O'Neil 1977). In contrast, the oxygen isotope stratigraphy indicates that the Albian and early Cenomanin were exceptionally unperturbed.

Carbon isotope compositions are more variable than 
the oxygen isotope contents of the bulk carbonates (Fig. 2). $\delta^{13} \mathrm{C}$ values vary between $1.9 \%$ and $3.6 \%$ in Aptian sediments, $-0.8 \%$ to $3.9 \%$ in the Albian section, and $2.8 \%$ to $3.1 \%$ in the Cenomanian deposits. These values nonetheless remain within the range of isotopic compositions of modern marine carbonates and therefore do not indicate major changes in carbon cycling during the time span they represent.

\section{Organic carbon concentrations}

Concentrations of organic carbon are low, particularly in the Albian sediments where they average $0.2 \%$ (Fig. 2). Concentrations in both the upper Aptian and lower Cenomanian sections are higher than in the Albian section, and they reach values of more than $0.6 \%$ and $0.4 \%$, respectively. None of these TOC values is indicative of enhanced delivery of organic matter to these slowly accumulating sediments. This sequence, which provides a complete record of Albian sediment accumulation, contrasts significantly with other Albian sequences in which black shales occur.

Albian organic-carbon-rich black shales were deposited nearby in the Neo-Tethys. Organic carbon ranges between 0.7 and $2.1 \%$ in black claystones from DSDP site 263 (Fig. 1) on the eastern edge of the Cuvier Abyssal Plain (Bode 1974). Although initially interpreted as being a subsided shallow-water deposit because of silty layers (Heirtzler et al. 1974), the site 263 black shales are more likely to be turbiditic deep-water deposits similar to those described on basin margins of the Atlantic Ocean by Dean et al. (1984). Organic carbon isotopic measurement of an Albian sediment sample from site 263 gave a $\delta^{13} \mathrm{C}$ value of $-24.6 \%$ (Erdman et al., 1974). This sample, containing $0.7 \%$ organic carbon and having an isotopic value intermediate between continental and modern marine organic carbon (Emerson and Hedges 1988; Jasper and Gagosian 1989; Meyers 1994), probably contains a mixture of terrigenous and marine organic matter from a shelf-edge upwelling zone, which is consistent with a turbiditic origin.

\section{Organic matter $\mathrm{C} / \mathrm{N}$ ratios}

$\mathrm{C} / \mathrm{N}$ ratios help to distinguish between contributions of algal-derived organic matter and those of organic matter produced by vascular plants on land. Marine algae are relatively enriched in lipids and proteins; the $\mathrm{C} / \mathrm{N}$ ratios of their organic matter are therefore low. Land plants typically contain large proportions of woody and fibrous structural tissue made up of cellulose and lignin; their $\mathrm{C} / \mathrm{N}$ ratios are high. Average ranges of $\mathrm{C} / \mathrm{N}$ values are 5-8 for marine organic matter and 20 to more than 100 for land material (Emerson and Hedges 1988; Jasper and Gagosian 1989; Meyers 1994).

Several processes complicate the use of $\mathrm{C} / \mathrm{N}$ ratios as indicators of the sources of organic matter in marine sedi-

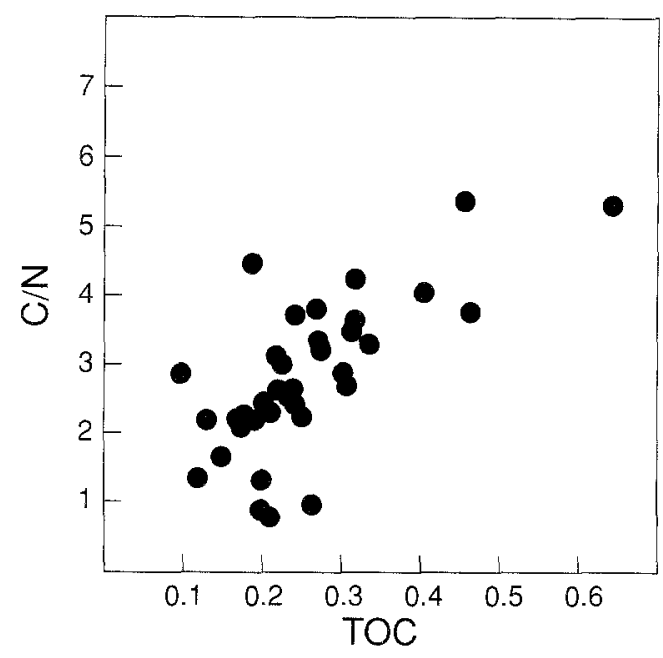

Fig. 3 Comparison of organic carbon concentrations (TOC) and organic matter atomic $\mathrm{C} / \mathrm{N}$ ratios of sediments from hole $763 \mathrm{~B}$. Correspondence between low TOC and low $\mathrm{C} / \mathrm{N}$ values indicates that the amount of preservation of the marine organic matter in these sediments has been variable

ments. Müller (1977) observed that ammonia can absorb onto illite in marine sediments, thereby depressing organic matter $\mathrm{C} / \mathrm{N}$ ratios unless allowance is made for the inorganic nitrogen. This effect is more important in clay-rich sediments than in biogenic oozes, and it must be considered in marly sediments like those at site 763 . Furthermore, Waples and Sloan (1980) described decreases in C/N ratios with sediment age in DSDP leg 58 holes in the western North Pacific. The ratios changed from ca. 9 in Holocene sediments to ca. 4 in lower Pliocene deposits. They concluded that this trend reflects postdepositional diagenesis and selective degradation of carbon-rich components of organic matter in deeper and older sediments.

Virtually all of the site $763 \mathrm{C} / \mathrm{N}$ ratios (Fig. 2) fall below the value of 4 that is the lower limit of living algae (Meyers 1994). These values probably result from ammonia derived from breakdown of organic matter being sorbed onto clays in the sediment (Stevenson and Cheng 1972, Müller 1977). The low $\mathrm{C} / \mathrm{N}$ values indicate the diagenetic loss of marine organic carbon and consequently are indirect evidence of diminished organic matter preservation. Comparison of TOC concentrations and $\mathrm{C} / \mathrm{N}$ ratios (Fig. 3) substantiates the interpretation that lower concentrations of organic carbon and poorer preservation of marine organic matter are linked in the site 763 sediments.

\section{Organic carbon $\delta^{13} \mathrm{C}$ values}

Organic carbon isotopic ratios are useful to distinguish between marine and continental plant sources of sedimentary organic matter. Most photosynthetic plants incorporate carbon into organic matter using the $\mathrm{C}_{3}$ Calvin pathway, which biochemically discriminates against ${ }^{13} \mathrm{C}$ to produce a $\delta^{13} \mathrm{C}$ shift of about $-20 \%$ from the isotope 
ratio of the inorganic carbon source. Organic matter produced from atmospheric $\mathrm{CO}_{2}\left(\delta^{13} \mathrm{C} \approx-7 \%\right)$ by land plants using the $\mathrm{C}_{3}$ pathway consequently has an average $\delta^{13} \mathrm{C}$ (PDB) value of ca. $-27 \%$ (O'Leary 1988; Meyers 1994). The source of inorganic carbon for marine algae is dissolved bicarbonate, which has an interglacial $\delta^{13} \mathrm{C}$ value of ca. $0 \%$. Modern marine organic matter consequently typically has $\delta^{13} \mathrm{C}$ values between $-20 \%$ and $-22 \%$. (Emerson and Hedges 1988; Jasper and Gagosian 1989; Meyers 1994; Prahl et al. 1994). The $\approx 7 \%$ difference between organic matter produced by $\mathrm{C}_{3}$ land plants and marine algae has been used to trace the delivery and distribution of organic matter to sediments of ocean margins (Newman et al. 1973; Prahl et al. 1994) and should therefore be useful to identify changes in sources of organic matter in the sediments at site 763 .

Carbon isotope ratios of sedimentary organic matter can be affected by photosynthetic dynamics and by postdepositional diagenesis (Dean et al. 1986) and consequently must be interpreted cautiously. The effects of selective diagenesis of organic matter fractions that are isotopically heavy or light appear to be small, usually much less than 2\% (Hayes et al. 1989; Fontugne and Calvert 1992; McArthur et al. 1992; Meyers 1994). Increased availability of dissolved $\mathrm{CO}_{2}$ to algae, however, would enhance their isotopic discrimination and produce marine organic matter that is isotopically light (Hayes et al. 1989). Modern algae inhabiting the Southern Ocean generally have light $\delta^{13} \mathrm{C}$ values, between $-26 \%$ and $-30 \%$, because of the enhanced solubility of $\mathrm{CO}_{2}$ in the cold waters ( $\mathrm{Rau}$ et al. 1989). Moreover, fluvial delivery of isotopically light dissolved inorganic carbon to coastal waters would similarly result in isotopically light marine organic matter (Fontugne and Calvert 1992).

The $\delta^{13} \mathrm{C}$ values of the site 763 sediments are notably lighter than most modern marine organic matter and instead are more like those found in the modern Southern Ocean by Rau et al. (1989). The range of values, from $-25 \%$ to $-34 \%$, could indicate that a major proportion of land-derived organic matter is present in these sediments, but this interpretation would conflict with the low $\mathrm{C} / \mathrm{N}$ ratios, which suggest that algal organic matter is in fact dominant. Modern Southern Ocean algae produce organic matter that is isotopically light because dissolved $\mathrm{CO}_{2}$ concentrations are high in the cold waters of these boreal latitudes. Although the paleo-position of site 763 was in latitudes equivalent to those of today's Southern Ocean, it is not likely that surface waters during the icefree Albian were as cool as they presently are at these latitudes. The very light organic $\delta^{13} \mathrm{C}$ values in the site 763 sections are probably the result of elevated dissolved $\mathrm{CO}_{2}$, rather than low temperatures. Instead, globally low rates of $\mathrm{CO}_{2}$ removal from seawater, a consequence of low marine productivity, would encourage discrimination against ${ }^{13} \mathrm{C}$ uptake during photosynthesis. The very light $\delta^{13} \mathrm{C}$ values and accompanying exaggerated difference between carbonate and organic $\delta^{13} \mathrm{C}$ values (Fig. 2) therefore are an indication of generally low productivity in the NeoTethys Ocean during the Early Cretaceous.

\section{Discussion and conclusions}

Depositional settings of Albian black shales

Albian black shales are mostly strongly expressed in the Atlantic Ocean and surrounding continental areas (Hallam 1987). Their origin remains controversial. Zimmerman et al. (1987) conclude that episodes of deep-water anoxia were involved in black shale deposition in the South Atlantic, which existed as a group of silled basins in the mid-Cretaceous. These episodes facilitated organic mater preservation. Paleo-climate models of Parrish have indicated that the locations at which black shales accumulated correspond to areas of paleo-upwelling and therefore enhanced oceanic paleo-productivity. Rapid sedimentation from turbidity flows and consequent improved preservation of organic matter has been argued as the principal factor leading to Albian black shale deposition in both the North Atlantic (Summerhayes 1987) and the South Atlantic (Dean et al. 1984; Stow 1987). An important implication of the latter scenario is that deep-sea black shale deposits would be strongly influenced by regional or local supplies of organic matter and of sediments from ocean margins and surrounding land areas, although the timing of their occurrence might still be controlled by global processes such as sealevel change.

\section{Significance of the site 763 section}

The accumulation of organic matter in the Albian sequence in hole 763B is monotonously low, and the absence of organic-carbon-rich black shales in this apparently complete section contrasts to the common occurrence of black shales in sediments of this age from other parts of the world. A combination of low biological productivity and low sediment accumulation rates evidently contributed to the absence of Albian black shales on the Exmouth Plateau.

Most of the Aptian-Albian black shales that have been described in deep-sea settings have been parts of continental rise turbidite sequences (Dean et al. 1984; Stow 1987; Summerhayes 1987). The isolation of the Exmouth Plateau from the Australian continent excluded delivery of coarser terrigenous sediments to this site and thereby diminished sediment accumulation rates starting in the Aptian. This factor evidently precluded turbidite deposition at site 763 and, consequently, did not allow black shale deposition during the Albian. The sediments from site 763 may better represent typical open-ocean paleoconditions during the Early Cretaceous than sediments from the basin-edge sites at which black shales have been found. This observation suggests that the most important element in formation of Early Cretaceous black shales was rapid sediment accumulation; neither basin-wide anoxia nor elevated productivity was required. 
Acknowledgments I thank S. M. Bernasconi and W. G. Siesser for discussions and suggestions that helped to improve this contribution. E. A. Kowalski assisted with laboratory analyses. Samples were provided by the Ocean Drilling Program, supported by the US National Science Foundation. This project was supported in part by a grant from the Joint Oceanographic Institutions ODP US Science Support Program.

\section{References}

Arthur MA, Dean WE, and Stow DAV (1984) Models for the deposition of Mesozoic-Cenozoic fine-grained organic-carbon-rich sediment in the deep sea. In: Stow DAV and Piper DJW (Eds.), Fine-Grained Sediments: Deep-Water Processes and Facies. Oxford: Blackwell Scientific Publications. pp 527-560

Barron EJ, Harrison CG, Sloan JL, and Hay WW (1981) Paleogeography, 180 million years to the present. Eclogae Geologia Helvetica 74:443-470

Berger WH (1970) Planktonic foraminifera: Selective solution and the lysocline. Marine Geology 8:111-138

Berger WH, Bonneau M-C, and Parker FL (1982) Foraminifera on the deep-sea floor; Lysocline and dissolution rate. Oceanologica Acta 5:249-258

Bode GW (1974) Carbon and carbonate analyses, leg 27. In: Heirtzler JR, Veevers JJ, Shipboard Scientific Party (Eds.), Initial Reports of the Deep Sea Drilling Project, 27. Washington, DC: US Government Printing Office. pp 499-502

Bralower TJ (1992) Aptian-Albian calcareous nannofossil biostratigraphy of ODP site 763 and the correlation between high- and low-latitude zonations. In: Duncan R, Kidd R, Rea D, von Rad U, and Weissel J (Eds.), Synthesis of Results from Scientific Drilling in the Indian Ocean. Washington, DC: American Geophysical Union. pp 245-252

Bralower TJ and Siesser WG (1992) Cretaceous calcareous nannofossil biostratigraphy of ODP site 761, 762, and 763. Exmouth and Wombat plateaus, NW Australia. In: Haq B, von Rad U, Shipboard Scientific Party (Eds.), Proceedings Ocean Drilling Program, Scientific Results, 122: College Station, Texas: Ocean Drilling Program. pp 529-556

Dean WE, Gardner JV, and Cepek P (1981) Tertiary carbonatedissolution cycles on the Sierra Leone Rise, eastern equatorial Atlantic Ocean. Marine Geology 39:81-101

Dean WE, Arthur MA, and Stow DAV (1984) Origin and geochemistry of Cretaceous deep-sea block shales and multicolored claystones, with emphasis on Deep Sea Drilling Project site 530, southern Angola Basin. In: Hay WW, Sibuet J-C, Shipboard Scientific Party (Eds.), Initial Reports Deep Sea Drilling Project, 75. Washington, DC: US Government Printing Office. pp 819 844

Dean WE, Arthur MA, and Claypool GE (1986) Depletion of ${ }^{13} \mathrm{C}$ in Cretaceous marine organic matter: Source, diagenetic, or environmental signal? Marine Geology 70:119-157

Ditchfield P and Marshall JD (1989) Isotopic variation in rhythmically bedded chalks: Paleotemperature variation in the Upper Cretaceous. Geology 17:842-845

Emerson S and Bender M (1982) Carbon fluxes at the sedimentwater interface of the deep-sea: Calcium carbonate preservation. Journal of Marine Research 39:139-162

Emerson S and Hedges J (1988) Processes controlling the organic carbon content of open ocean sediments. Paleoceanography $3: 621-634$.

Erdman JG, Schorno KS, and Scanlan RS (1974) Geochemistry of carbon: DSDP legs 22, 24, 26, 27, and 28. In: Fisher RL, Bunce ET, Shipboard Scientific Party (Eds.), Initial Reports of the Deep Sea Drilling Project, 24. Washington, DC: US Government Printing Office. pp 1169-1176

Exon NF, von Rad U, and von Stackelberg U (1982) The geological development of the passive margins of the Exmouth Plateau off northwest Australia. Marine Geology 47:131-152
Fontugne MR and Calvert SE (1992) Late Pleistocene variability of the carbon isotopic composition of organic matter in the Eastern Mediterranean: Monitor of changes in carbon sources and atmospheric $\mathrm{CO}_{2}$ concentrations. Paleoceanography 7:1-20

Friedman I and O'Neil JR (1977) Compilation of stable isotope fractionation factors of geochemical interests. In: Fleisher $\mathrm{M}$. (Ed.), Data of Geochemistry, 6th ed. U.S.G.S. Prof. Paper 440KK. pp KK1-KK 12

Gradstein FM, Ludden J, Adamson AC, and Shipboard Scientific Party (1990) Proceedings Ocean Drilling Program, Initial Reports, 123. College Station, Texas: Ocean Drilling Program

Hallam A (1987) Mesozoic marine organic-rich shales, In: Brooks J and Fleet AJ (Eds.), Marine Petroleum Source Rocks. Oxford: Blackwell Scientific Publishers. pp 251-261

Haq BU, von Rad U, O'Connell S, and Shipboard Scientific Party (1990) Proceedings Ocean Drilling Program, Initial Reports, 122. College Station, Texas: Ocean Drilling Program

Hayes JM, Popp BN, Takigiku R, and Johnson MW (1989) An isotopic study of biogeochemical relationships between carbonates and organic carbon in the Greenhorn Formation. Geochimica et Cosmochimica Acta 53:2961-2972

Heirtzler JR, Veevers JJ, and Shipboard Scientific Party, Site 263. (1974) Initial Reports of the Deep Sea Drilling Project, 27. Washington, DC: US Government Printing Office. pp 279-335

Jasper JP and Gagosian R (1989) Glacial-interglacial climatically forced ${ }^{13} \mathrm{C}$ variations in sedimentary organic matter. Nature $342: 60-62$

McArthur JM, Tyson RV, Thomson J, and Mattey D (1992) Early diagenesis of marine organic matter: Alteration of the carbon isotopic composition. Marine Geology 105:51-61

Meyers PA (1994) Preservation of elemental and isotopic source identification of sedimentary organic matter. Chemical Geology 114:289-302

Meyers PA and Dickens GR (1992) Accumulations of organic matter in sediments of the Indian Ocean: A synthesis of results from scientific deep sea drilling. In: Duncan $R$, Kidd R, Rea D, von Rad U, and Weissel J (Eds.), Synthesis of Results from Scientific Drilling in the Indian Ocean. Washington, DC: American Geophysical Union. pp 295-309

Müller PJ (1977) C/N ratios in Pacific deep sea sediments: Effect of inorganic ammonium and organic nitrogen compounds sorbed by clays. Geochimica et Cosmochimica Acta $41: 765-776$

Müiller G and Gastner M (1971) The "karbonate bomb," a simple device for determination of the carbonate content in sediments, soils, and other materials. Neues Jahrbuch für Mineralogie 10:446-469

Newman JW, Parker PL, and Behrens EW (1973) Organic carbon isotope ratios in Quaternary cores from the Gulf of Mexico. Geochimica et Cosmochimica Acta 37:225-238

O'Leary MH (1988) Carbon isotopes in photosynthesis. Bioscience $38: 328-336$

Parrish JT (1987) Palaeo-upwelling and the distribution of organicrich rocks. In: Brooks J and Fleet AJ (Eds.), Marine Petroleum Source Rocks. Oxford: Blackwell Scientific Publishers. pp 199 205

Prahl FG, Ertel JR, Goni MA, Sparrow MA, and Eversmeyer B (1994) Terrestrial organic carbon contributions to sediments on the Washington margin. Geochimica et Cosmochimica Acta 58: 3055-3048

Rau GH, Takahashi T, and Des Marais DJ (1989) Latitudinal variations in plankton $\delta^{13} \mathrm{C}$ : Implications for $\mathrm{CO}_{2}$ and productivity in past oceans. Nature 341:516-518

Shackleton NJ and Hall MA (1984) Carbon isotope data from leg 74 sediments. In: Moore TC, Rabinowitz PD, Shipboard Scientific Party (Eds.), Initial Reports of the Deep Sea Drilling Project, 74. Washington, DC: US Government Printing Office. pp 613619

Shackleton NJ, Hall MA, and Pate D (1993) High-resolution stable isotope stratigraphy from bulk sediment. Paleoceanography 8 : 141-148

Snowdon LR and Meyers PA (1992) Source and maturity of organic matter in sediments and rocks from Ocean Drilling Program sites $759,760,761$, and 764, Wombat Plateau, and site 762 and 763 , 
Exmouth Plateau. In: Haq B, von Rad U, Shipboard Scientific Party (Eds.), Proceedings Ocean Drilling Program, Scientific Results, 122. College Station, Texas: Ocean Drilling Program. pp 309-315

Stein R, Rullkötter J, and Welte DH (1989) Changes in paleoenvironments in the Atlantic Ocean during Cretaceous times: Results from black shales studies. Geologische Rundschau 78:883-901

Stevenson FJ and Cheng C-N (1972) Organic geochemistry of the Argentine Basin sediments: Carbon-nitrogen relationships and Quaternary correlations. Geochimica et Cosmochimica Acta 36: 653-671

Stow DAV (1987) South Atlantic organic-rich sediments: facies processes and environments of deposition. In: Brooks $\mathbf{J}$ and Fleet AJ (Eds.), Marine Petroleum Source Rocks. Oxford: Blackwell Scientific Publishers. pp 287-299

Summerhayes CP (1987) Organic-rich Cretaceous sediments from the North Atlantic. In: Brooks $\mathbf{J}$ and Fleet $\mathrm{AJ}$ (Eds.), Marine Petroleum Source Rocks. Oxford: Blackwell Scientific Publishers. pp 301-316
Verardo DJ, Froelich PN, and McIntyre A (1990) Determination of organic carbon and nitrogen in marine sediments using the Carlo Erba NA01500 analyzer. Deep-Sea Research 37:157-165

Waples DW and Sloan JR (1980) Carbon and nitrogen diagenesis in deep sea sediments. Geochimica et Cosmochimica Acta 44: $1463-1470$

Weissert H and Bréhéret JG (1991) A carbonate carbon-isotope record from Aptian-Albian sediments of the Vocontian trough (SE France). Bulletin de la Societé géologique de France 162:11331140

Yamamura M and Kayanne H (1995) Rapid direct determination of organic carbon and nitrogen in carbonate-bearing sediments with a Yanaco MT-5 CHN analyzer. Limnology and Oceanography 40:1001-1005

Zimmerman HB, Boersma A, and McCoy FW (1987) Carbonaceous sediments and palaeoenvironment of the Cretaceous South Atlantic Ocean. In: Brooks J and Fleet AJ (Eds.), Marine Petroleum Source Rocks. Oxford: Blackwell Scientific Publishers. pp 271286 